\title{
Karakteristik Perpindahan Panas dan Penurunan Tekanan Sirip- sirip Pin Silinder Tirus Susunan Segaris dan Selang-seling dalam Saluran Segi Empat
}

\author{
Tri Istanto dan Wibawa Edra Juwana \\ Lab. Perpindahan Panas \& Termodinamika, Teknik Mesin, UNS, Surakarta \\ Email: triis_meuns2000@yahoo.com, wibawa.ej@gmail.com
}

\begin{abstract}
ABSTRAK
Penelitian ini dilakukan untuk menguji karakteristik perpindahan panas dan penurunan tekanan dari susunan sirip-sirip pin silinder tirus dalam saluran udara segiempat. Sirip-sirip pin disusun secara segaris dan selang-seling. Temperatur rata-rata permukaan plat dasar dijaga konstan sebesar $60^{\circ} \mathrm{C}$. Sirip-sirip pin terbuat terbuat dari bahan duralumin dengan tinggi 75 $\mathrm{mm}$, diameter dasar dan diameter ujung berturut-turut $12,7 \mathrm{~mm}$ dan $7 \mathrm{~mm}$, dan jarak antar titik pusat sirip dalam arah melintang aliran udara, $S_{x} / D$ konstan, sebesar 2,95. Parameterparameter dalam penelitian ini adalah bilangan Reynolds antara 3.100 hingga 39.200 pada susunan segaris dan antara 3.095 hingga 37.741 pada susunan selang-seling berdasarkan kecepatan aliran udara masuk rata-rata dan diameter hidrolik, dan jarak antar titik pusat sirip arah aliran udara, $S_{y} / D$, divariasi sebesar 1,97, 2,36, 2,95, dan 3,94. Hasil penelitian ini menunjukkan bahwa pada kedua susunan sirip pin, peningkatan bilangan Reynolds dan semakin kecil jarak $S_{y} / D$ akan meningkatkan bilangan Nusselt, yang berarti meningkatkan laju perpindahan panas, dimana mencapai maksimum pada $S_{y} / D=2,36$. Nilai penurunan tekanan dan faktor gesekan menurun dengan meningkatnya $S_{y} / D$.
\end{abstract}

Kata kunci: Sirip pin, silinder tirus, bilangan Reynolds, bilangan Nusselt, faktor gesekan.

\begin{abstract}
This research was conducted to investigate the characteristics of heat transfer and pressure drop of tapered cylindrical pin fins array in the rectangular channel. The pin fins were arranged either inline or staggered. The average temperature of base plate surface was kept constant at $60^{\circ} \mathrm{C}$. Pin fins were made of duralumin having the dimension of $75 \mathrm{~mm}$ of height, base and tip diameter 12.7 and $7 \mathrm{~mm}$ respectively, and the distance inter-fin pitch in the spanwise direction, $S_{x} / D$, was kept constant at 2.95. The parameters of this research were Reynolds number 3,100-39,200 for the inline array and 3,095 - 37,741 for the staggered array based on averaged inlet air velocity and hydraulic diameter, and the distance between the inter-fin pitch in the streamwise direction, $S_{y} / D$, was varied at 1.97, 2.36, 2.95, and 3.94. The research result shows that for both fin arrangements increasing Reynolds number and decreasing the distance $S_{y} / D$ increases Nusselt number, that means increases heat transfer rate where it reaches maximum at $S_{y} / D=2.36$. The values of pressure drop $(\Delta P)$ and friction factor (f) decreases with increasing $S_{y} / D$.
\end{abstract}

Keywords: Pin fin, tapered cylindrical, Reynolds number, Nusselt number, friction factor.

\section{PENDAHULUAN}

Sirip digunakan pada alat penukar kalor untuk meningkatkan luasan perpindahan panas antara permukaan utama dengan fluida di sekitarnya. Idealnya, material untuk membuat sirip harus memiliki konduktivitas termal yang tinggi untuk meminimalkan perbedaan temperatur antara permukaan utama dengan permukaan yang diperluas. Aplikasi sirip sering dijumpai pada sistem pendinginan ruangan, peralatan elektronik, motor bakar, trailing edge sudu turbin gas, alat penukar kalor kompak, dengan udara sebagai media perpindahan panasnya. Ada berbagai tipe sirip pada alat penukar kalor yang telah digunakan, mulai dari bentuk yang relatif sederhana seperti sirip segiempat, silindris, anular, tirus atau pin sampai dengan kombinasi dari berbagai geometri yang berbeda dengan jarak yang teratur dalam susunan segaris (in-line) ataupun selang-seling (staggered). 
Salah satu tipe sirip pada peralatan penukar kalor yang mempunyai banyak pemakaian dalam berbagai aplikasi industri adalah sirip pin. Sirip pin adalah elemen berbentuk silinder atau bentuk lainnya yang dipasang secara tegak lurus terhadap dinding alat penukar kalor dengan fluida pendingin mengalir dalam arah aliran melintang terhadap dinding alat penukar kalor tersebut. Sirip-sirip pin dapat meningkatkan luas permukaan pelepas panas, dan menyebabkan aliran yang turbulen sehingga meningkatkan unjuk kerja disipasi panas yang berdampak pada meningkatnya ketahanan dan umur peralatan. Terdapat berbagai parameter yang menggolongkan sirip pin, seperti bentuk pin, tinggi pin, diameter pin, perbandingan tinggi dan diameter pin dan sebagainya yang dapat disusun secara segaris ataupun secara selang-seling terhadap arah aliran fluida pendinginnya

Laju perpindahan panas dari suatu rakitan sirip pin ke lingkungan tergantung pada distribusi temperatur pada sirip pin dan plat dasar, geometri sirip pin, jarak antara ujung sirip pin dengan permukaan atas saluran udara (shroud clearance), sifat-sifat fluida, laju aliran udara, jarak antara titik pusat sirip (inter-pin pitch), susunan sirip pin dan orientasi dari alat penukar kalor. Laju perpindahan panas pada plat dasar dengan temperatur tertentu dapat ditingkatkan dengan menaikkan koefisien perpindahan panas rata-rata, menaikkan luas permukaan perpindahan panas atau kedua-duanya. Kenaikan perpindahan panas dapat dicapai dengan cara konveksi paksa atau mengubah konfigurasi geometri dari alat penukar panas. Dalam praktiknya, cara-cara ini dibatasi oleh penurunan tekanan maksimum yang diijinkan melalui susunan sirip pin tersebut karena kenaikan perpindahan panas akan disertai penurunan tekanan. Energi yang hilang karena penurunan tekanan dapat melebihi energi yang didapatkan dari usaha peningkatan perpindahan panas tersebut.

\section{METODE PENELITIAN}

Spesimen terdiri atas plat dasar dengan panjang $200 \mathrm{~mm}$, lebar $150 \mathrm{~mm}$ dan tebal $6,5 \mathrm{~mm}$ yang dipasangi sejumlah sirip pin silinder tirus pejal yang disusun secara segaris dan selang-seling dengan tinggi $75 \mathrm{~mm}$, diameter dasar 12,7 $\mathrm{mm}$ dan diameter ujung $7 \mathrm{~mm}$. Bahan plat dasar dan sirip pin adalah duralumin.

Pengujian dilakukan dengan variasi kecepatan aliran udara masuk seksi uji sebesar 0,5, 1, 2, 3, 4, 5, 5,5 dan $6 \mathrm{~m} / \mathrm{s}$, dan jarak antar titik pusat sirip dalam arah aliran udara (streamwise direction) yaitu sebesar 25, 30, 37,5 dan $50 \mathrm{~mm}$.

Skema alat penelitian ini dapat dilihat pada Gambar 3. Saluran udara segiempat dibuat menggunakan triplek berlapiskan melamin dengan rangka kayu, dengan dimensi 150 x 75 x 2.000 mm. Pemanas elektrik dibuat dari lilitan pita nikelin dengan panjang $4 \mathrm{~m}$, lebar $3 \mathrm{~mm}$, dan tebal 1,3 $\mathrm{mm}$ yang dililitkan pada kertas mika tahan panas dengan dimensi panjang $200 \mathrm{~mm}$, lebar $150 \mathrm{~mm}$, dan tebal $1 \mathrm{~mm}$.

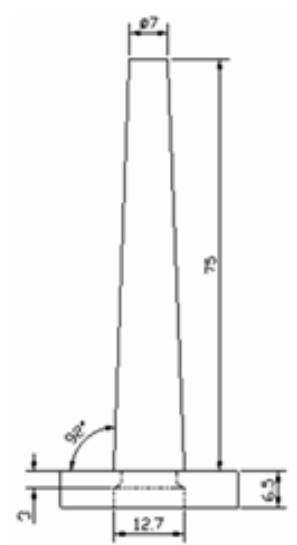

a) Dimensi Sirip

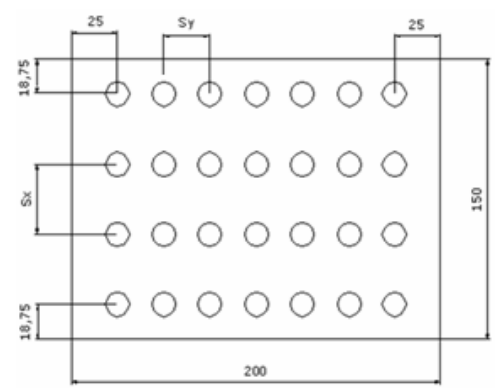

b) Dimensi Plat Dasar

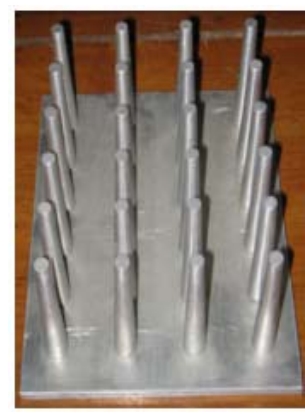

c) Spesimen Penelian

Gambar 1. Spesimen Penelitian Susunan Segaris

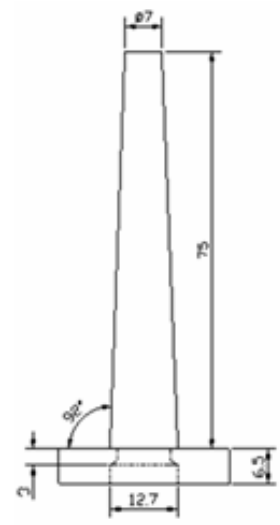

a) Dimmensi Sirip Pin

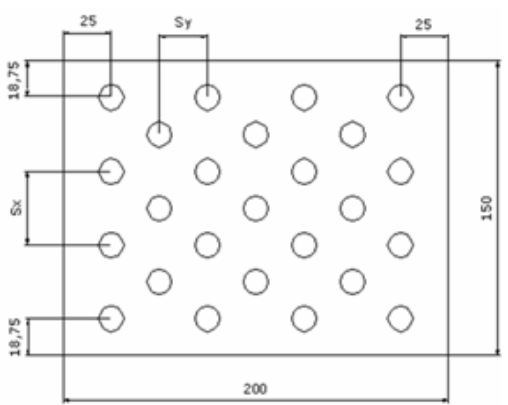

b) Dimensi Plat Dasar

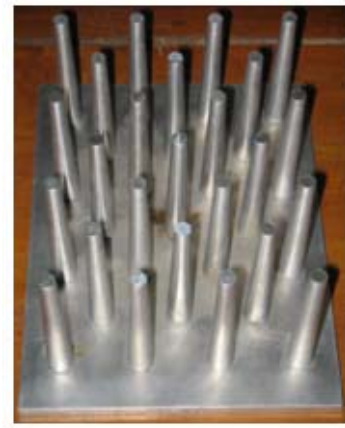

c) Spesimen Penelitian
Gambar 2. Spesimen Penelitian Susunan Selangseling 


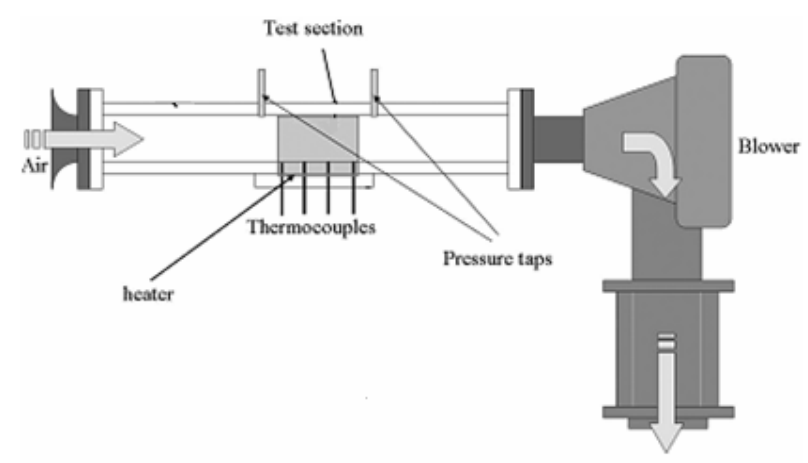

(a) Skema Alat Penelitian

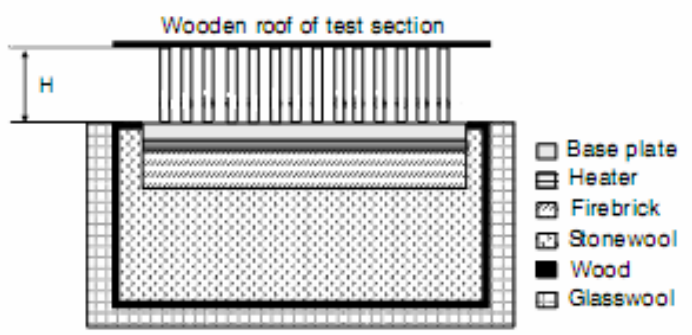

(b) Potongan Seksi Uji

Gambar 3. Skema Alat Penelitian dan Seksi Uji

Pengukuran temperatur dilakukan di 17 titik, menggunakan termokopel tipe T. Tiga termokopel dipasang pada saluran udara masuk untuk mengukur temperatur udara masuk sebelum melewati seksi uji, 5 termokopel pada saluran udara keluar setelah melewati seksi uji untuk mengukur temperatur udara keluar seksi uji, dan 9 termokopel dipasang pada permukaan plat dasar untuk mengukur temperatur permukaan plat dasar. Untuk mengukur penurunan tekanan udara yang terjadi antara sisi masuk dan sisi keluar seksi uji, digunakan manometer tipe U. Pengujian dilakukan pada temperatur udara masuk saluran segiempat yang konstan sebesar $26^{\circ} \mathrm{C}$ dan temperatur plat dasar yang konstan sebesar $60^{\circ} \mathrm{C}$. Pada penelitian ini data-data temperatur dan beda tinggi fluida manometer pada kondisi tunak.

\section{Perhitungan Perpindahan Panas}

Kesetimbangan energi pada kondisi tunak untuk permukaan uji yang dipanaskan secara elektrik adalah sebagai berikut:

$Q_{\text {elect }}=Q_{\text {conv }}+Q_{\text {loss }}$

Masukan panas listrik dihitung dari tegangan listrik dan arus listrik yang disuplai ke permukaan plat dasar. Kehilangan panas dari sistem bisa terjadi karena radiasi dan konduksi melalui dindingdinding saluran ke atmosfer. Sehingga Persamaan 1 ditulis menjadi:

$Q_{\text {elect }}=Q_{\text {conv }}+Q_{\text {rad }}+Q_{\text {cond }}$

Pada penelitian terdahulu [1, 2], melaporkan bahwa total kehilangan panas karena radiasi dari permukaan uji sekitar 0,5\% dari total input panas listrik, sehingga kehilangan panas karena radiasi diabaikan. Kehilangan panas karena konduksi dari sisi dinding-dinding dapat diabaikan dibandingkan dari permukaan bawah dari seksi uji, karena luas total sisi plat yang dipanaskan jauh lebih kecil dari luas permukaan bawah. Pada penelitian ini, permukaan bawah dari plat uji disolasi dengan kombinasi lapisan isolator dan lapisan kayu, sehingga kehilangan panas karena konduksi dapat diminimalisasi. Analisis data akan memuaskan jika persentase total kehilangan panas, $\left(Q_{\text {elect }}-Q_{\text {conv }}\right) / Q_{c o n v}$ kurang dari 10\% [3]. Sehingga Persamaan 2 menjadi:

$Q_{\text {elect }}=Q_{\text {conv }}$

Panas yang dipindahkan dari permukaan bersirip dengan cara konveksi adalah:

$Q_{\text {conv }}=\dot{m} \cdot C_{p}\left(T_{\text {aut }}-T_{i m}\right)$ dengan:

Dari Persamaan 4, $Q_{\text {conv }}$ dapat juga dinyatakan

$Q_{\text {conv }}=$ h.As. $\left[T_{b}-\left(\frac{T_{\text {in }}+T_{\text {sut }}}{2}\right)\right]$

Koefisien perpindahan panas konveksi rata-rata (h) dapat dihitung dengan menggunakan kombinasi Persamaan 4 dan 5 sehingga didapatkan bahwa:

$\mathrm{h}=\frac{\tilde{m}_{1} C_{p} \cdot\left(T_{\text {out }}-T_{\text {in }}\right)}{A_{s} \cdot\left[T_{b}-\left(\left(T_{\text {out }}+T_{\text {in }}\right) / 2\right)\right]}$

Laju aliran massa udara $(\dot{m})$ pada Persamaan 6, dihitung dengan menggunakan Persamaan 7: $\dot{m}=\rho . A_{t} . \mathrm{V}$

Untuk kasus dengan clearance nol seperti pada Gambar 4, maka $A_{t}$ dihitung dengan Persamaan 8: $\mathrm{A}_{\mathrm{t}}=\mathrm{H} . \mathrm{W}_{\mathrm{b}}$

$A_{s}$ adalah luas seluruh permukaan yang kontak dengan udara dari susunan sirip pin silinder tirus atau luas permukaan total dari permukaan plat dasar dan sirip pin silinder tirus. $A_{s}$ dihitung menggunakan Persamaan 9:

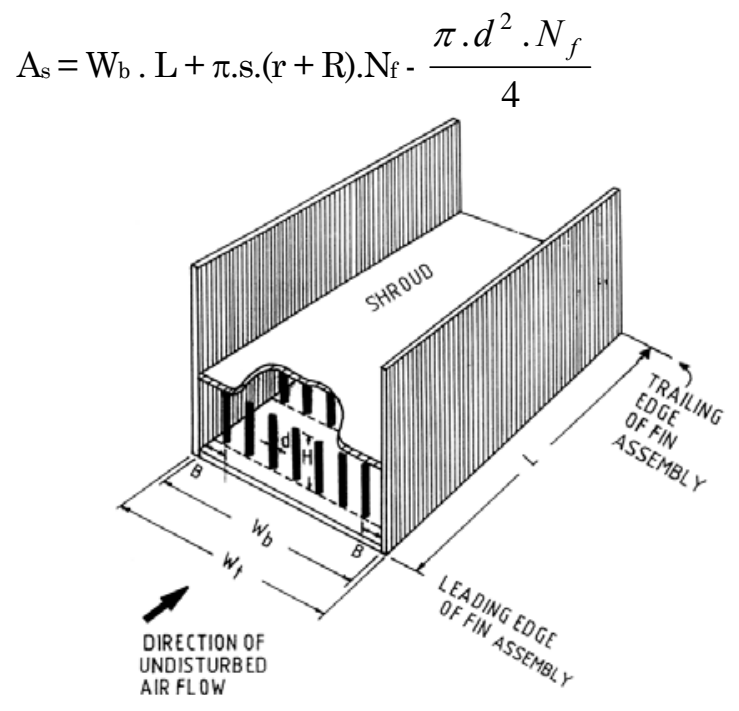

Gambar 4. Susunan Sirip Pin dalam Saluran Udara Segi Empat dengan Clearance Nol 
Nilai-nilai $T_{b}, T_{\text {in }}$ dan $T_{\text {out }}$ diukur dari penelitian yang dilakukan menggunakan termokopel. Sedangkan sifat termofisik udara, $C_{p}$ dihitung berdasarkan temperatur udara rata-rata, $T_{f}=\left(T_{\text {in }}+T_{\text {out }}\right) / 2$ menggunakan Persamaan 10 [4]:

$$
\begin{aligned}
\mathrm{C}_{\mathrm{p}}= & {\left[9,8185+7,7 \times 10^{-4}\left(\mathrm{~T}_{\text {in }}+\mathrm{T}_{\text {out }}\right) / 2\right] \mathrm{x} } \\
& 10^{2} \mathrm{~J} / \mathrm{kg} . \mathrm{K}
\end{aligned}
$$

Persamaan 10 berlaku untuk udara pada $250 \mathrm{~K}$ $\leq \frac{\mathrm{T}_{\text {in }}+\mathrm{T}_{\text {out }}}{2} \leq 400 \mathrm{~K}$ dan pada tekanan atmosfir.

Parameter tanpa dimensi yang digunakan dalam perhitungan perpindahan panas untuk permukaan bersirip dihitung sebagai berikut:

a. Bilangan Reynolds saluran (Re), dihitung berdasarkan kecepatan udara rata-rata $(V)$ dalam saluran halus dan diameter hidrolik saluran $\left(D_{h}\right)$. Re dihitung dengan Persamaan 11[5]

$$
R_{e}=\frac{\rho \cdot \mathrm{V} \cdot \mathrm{D}_{\mathrm{h}}}{\mu}
$$

b. Bilangan Nusselt rata-rata saluran $(\mathrm{Nu})$ dihitung menggunakan Persamaan 12 [5].

$$
\mathrm{Nu}=\frac{\mathrm{h} \cdot \mathrm{D}_{\mathrm{h}}}{\mathrm{k}}
$$

Properties udara, $\mu$ dan $k$ dihitung berdasarkan temperatur udara rata-rata, $T_{f}=\left(T_{\text {in }}+T_{\text {out }}\right) / 2$ menggunakan Persamaan 13 [4]:

$$
\mu=\left[4,9934+4,483 \times 10^{-2}\left(\mathrm{~T}_{\text {in }}+\mathrm{T}_{\text {out }}\right) / 2\right] \mathrm{x}
$$$$
10^{-6} \mathrm{~kg} / \mathrm{m} . \mathrm{s}
$$

$\mathrm{k}=\left[3,7415+7,495 \times 10^{-2}\left(\mathrm{~T}_{\text {in }}+\mathrm{T}_{\text {out }} / 2\right] \mathrm{x}\right.$ $10^{-3} \mathrm{~W} / \mathrm{m} . \mathrm{K}$

Persamaan 13 dan 14 berlaku untuk udara pada suhu $250 \mathrm{~K} \leq \frac{T_{\text {in }}+T_{\text {out }}}{2} \leq 400 \mathrm{~K}$ dan pada tekanan atmosfer.

\section{Perhitungan Faktor Gesekan}

Penurunan tekanan sepanjang seksi uji dalam saluran bersirip diukur pada kondisi aliran panas. Pengukuran ini dikonversi ke faktor gesekan $(f)$ yang ditentukan dari nilai pengukuran penurunan tekanan $(\Delta \mathrm{P})$, sepanjang seksi uji menggunakan Persamaan $15[5]$ :

$$
f=\frac{\Delta P}{\left[\left(\frac{L_{t}}{D_{h}}\right)\left(\rho \frac{V^{2}}{2}\right)\right]}
$$

\section{HASIL DAN PEMBAHASAN}

\section{Pengaruh Re dan Jarak Antar Titik Pusat Sirip dalam Arah Aliran Udara Pada Karakteristik Perpindahan Panas}

Perbandingan antara jarak antar titik pusat sirip pada arah aliran udara dan pada arah melintang dengan base diameter $\left(S_{y} / D\right.$ dan $\left.S_{x} / D\right)$, ditunjukkan di Tabel 1.
Tabel 1. Spesifikasi Spesimen

\begin{tabular}{ccccccc}
\hline Spesimen & $\begin{array}{c}S_{x} \\
(\mathrm{~mm})\end{array}$ & $S_{y}(\mathrm{~mm})$ & $S_{x} / D$ & $S_{y} / D$ & $\begin{array}{c}N_{f} \\
\text { (inline) }\end{array}$ & $\begin{array}{c}N_{f} \\
\text { (staggered) }\end{array}$ \\
\hline 1 & 37,5 & 25 & 2,95 & 1,97 & 28 & 25 \\
2 & 37,5 & 30 & 2,95 & 2,36 & 24 & 21 \\
3 & 37,5 & 37,5 & 2,95 & 2,95 & 20 & 18 \\
4 & 37,5 & 50 & 2,95 & 3,94 & 16 & 14 \\
\hline
\end{tabular}

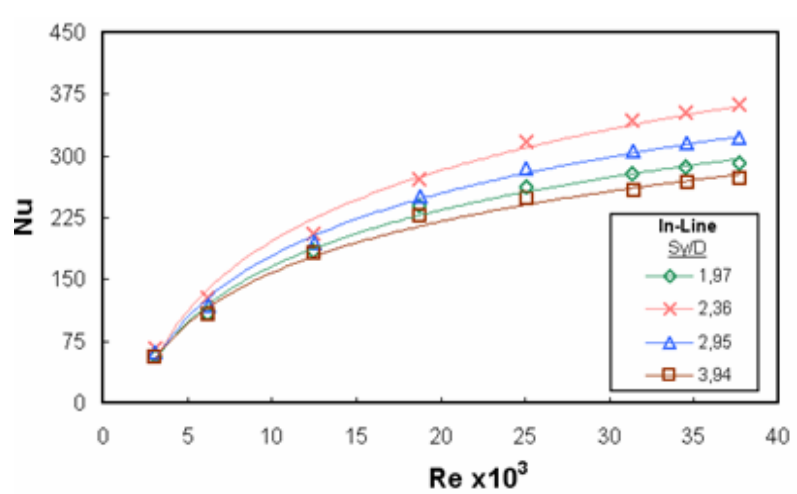

Gambar 5. Pengaruh $R e$ pada $N u$ Susunan Segaris

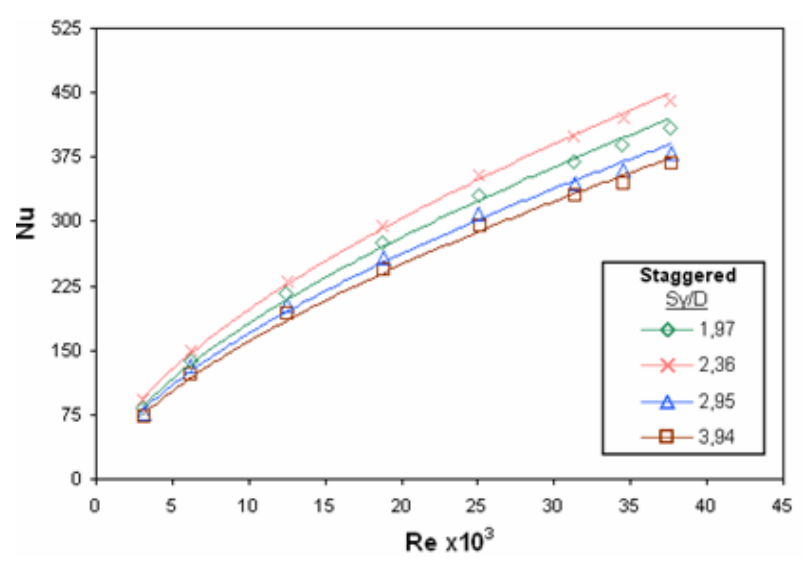

Gambar 6. Pengaruh Re pada $\mathrm{Nu}$ Susunan Selangseling

Pengaruh $R e$ pada perpindahan panas sirip pin susunan segaris dan selang-seling dapat dilihat pada Gambar 5 dan 6. Pada susunan selang-seling, nilai $\mathrm{Nu}$ rata-rata sedikit lebih tinggi dibandingkan pada susunan segaris untuk keseluruhan nilai $S_{y} / D$. Nu rata-rata meningkat dengan kenaikan $R e$. Hal ini terjadi pada keseluruhan nilai $S_{y} / D$. Peningkatan perpindahan panas ini berasal dari penurunan tebal lapis batas dengan kenaikan laju aliran udara [5]. Fenomena ini menunjukkan bahwa Re sangat berpengaruh pada laju perpindahan panas.

Gambar 7 dan 8 menunjukkan bahwa kenaikan $R e$, bersamaan dengan nilai $h$ rata-rata yang semakin besar. Pada susunan sirip selang-seling, nilai $h$ rata-rata sedikit lebih tinggi dibandingkan pada susunan segaris untuk keseluruhan nilai $S_{y} / D$. Semakin besar nilai $h$ rata-rata, maka semakin besar laju perpindahan panas konveksi 
yang terjadi. Susunan sirip pin selang-seling menghasilkan laju perpindahan konveksi yang lebih besar dibandingkan susunan segaris. Nilai $h$ ratarata meningkat dengan semakin kecilnya jarak antar titik pusat sirip pin dalam arah aliran udara $\left(S_{y}\right)$ Atau, semakin banyak sirip pin yang dipakai sampai pada nilai tertentu dan mencapai maksimal dimana penambahan sirip pin lebih lanjut atau nilai $S_{y}$ yang semakin kecil akan menurunkan $h$ nya.

Gambar 9 dan 10 menunjukkan perilaku $\mathrm{Nu}$ rata-rata terhadap $S_{y} / D$ pada $R e$ yang berbeda untuk susunan sirip pin segaris dan selang-seling. $S_{y} / D$ tidak terlalu berpengaruh terhadap $N u$. Nu sedikit meningkat dengan kenaikan $S_{y} / D$, dan mencapai maksimum pada $S_{y} / D=2,36$. Kemudian menurun kembali dengan kenaikan $S_{y} / D$. Sedangkan dari literatur [6,7] disebutkan bahwa perpindahan panas maksimum untuk susunan sirip pin silinder lurus (straight cylinder pin fin array) dicapai pada nilai $\mathrm{S}_{\mathrm{y}} / \mathrm{D}=2,5$.

Sirip-sirip pin, setelah baris pertama dari susunan sirip, adalah dalam jalur turbulen dari aliran bagian depan sirip-sirip pin. Untuk nilai $S_{y}$ sedang, koefisien konveksi yang berkaitan dengan aliran di baris sirip bagian belakang dipertinggi sebagai hasil aliran turbulen.

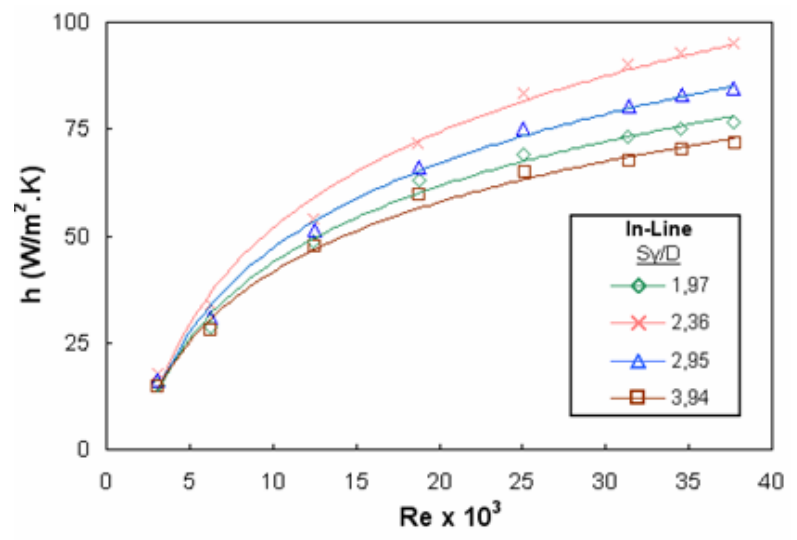

Gambar 7. Pengaruh Re pada $h$ pada Susunan Segaris

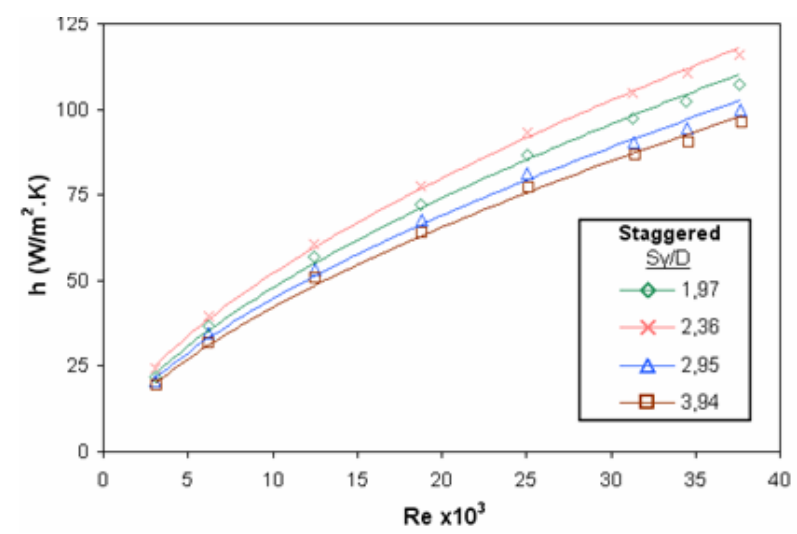

Gambar 8. Pengaruh Re pada $h$ Susunan Selangseling

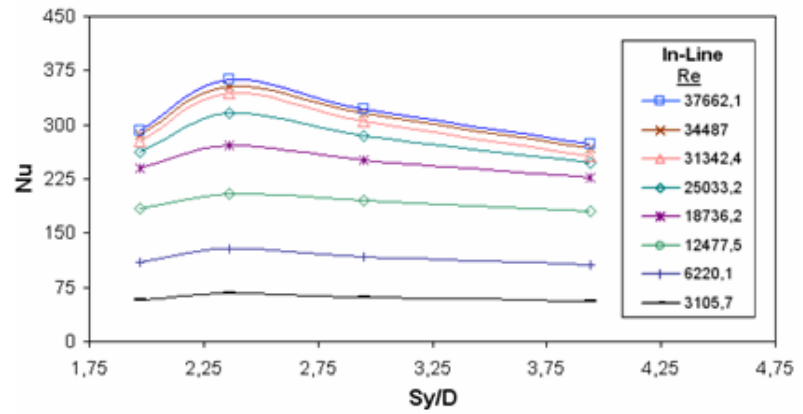

Gambar 9. Pengaruh $S_{y} D$ pada Nu Susunan Segaris

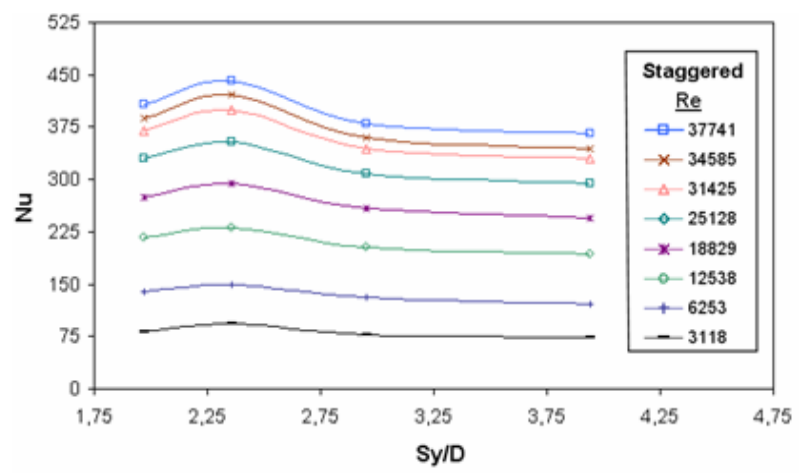

Gambar 10. Pengaruh $S_{y} / D$ pada Nu Susunan Selang-seling

Akan tetapi, untuk nilai $S_{y}$ yang kecil, barisbaris di bagian depan akan menghalangi laju aliran udara pada baris-baris di bagian belakang dan laju perpindahan panas akan berkurang [8]. Sehingga, lintasan aliran yang diinginkan dalam jalur antara sirip-sirip pin, sangat banyak permukaan sirip-sirip pin tidak terkena aliran utama terutama pada barisbaris bagian belakang. Untuk susunan sirip pin selang-seling, lintasan aliran utama lebih berlikuliku dibandingkan pada susunan sirip pin segaris, dan lebih besar bagian dari luasan permukaan siripsirip pin bagian belakang berada dalam lintasan ini [4].

Dari data-data penelitian ini dapat diperoleh korelasi matematis untuk karakteristik perpindahan panas dari sirip-sirip pin susunan segaris dan selang-seling. Korelasi antara $\mathrm{Nu}$ dengan $\mathrm{Re}$, jarak antar titik pusat sirip $\left(S_{y}\right)$ dan panjang spesimen uji $(L)$ adalah sebagai sebagai berikut [5]:

Untuk susunan segaris:

$\mathrm{Nu}=0,81 \cdot \operatorname{Re}^{0,545} \cdot\left(\mathrm{S}_{\mathrm{y}} / \mathrm{L}\right)^{-0,148}$

Korelasi perpindahan panas pada Persamaan 16 berlaku valid untuk range bilangan Reynolds $3.100<\operatorname{Re}<37.700, \mathrm{~L} / \mathrm{D}_{\mathrm{h}}=2$ dan $1,97<\mathrm{S}_{\mathrm{y}} / \mathrm{D}<3,94$. Untuk susunan selang-seling:

$\mathrm{Nu}=0,789 \cdot \mathrm{Re}^{0,601} \cdot\left(\mathrm{S}_{\mathrm{y}} / \mathrm{L}\right)^{0,07}$

Korelasi perpindahan panas pada Persamaan 17 berlaku valid untuk range bilangan Reynolds $3.095 \leq \operatorname{Re} \leq 37.741, \mathrm{~L} / \mathrm{D}_{\mathrm{h}}=2$ dan $1,97 \leq \mathrm{S}_{\mathrm{y}} / \mathrm{D} \leq 3,94$. 
Pengaruh Bilangan Reynolds dan Jarak Antar Titik Pusat Sirip dalam Arah Aliran Udara pada Penurunan Tekanan

Pengaruh bilangan Reynolds dan jarak antar titik pusat sirip pada arah aliran udara terhadap penurunan tekanan susunan sirip pin dapat dilihat pada Gambar 11, untuk susunan segaris dan Gambar 12 untuk susunan sirip pin selang-seling. Kelakuan $\Delta P$ pada $R e$ serupa dengan hasil penelitian terdahulu [9]. Dapat dilihat bahwa penambahan sirip-pin dengan susunan segaris dan selang-seling, menyebabkan penurunan tekanan yang signifikan dibandingkan dengan permukaan tanpa sirip-sirip (smooth surface). Nilai $\Delta \mathrm{P}$ semakin kecil dengan kenaikan $S_{y} / D$. Hal ini disebabkan karena dengan semakin besarnya $S_{y} / D$, maka jumlah sirip pin akan semakin berkurang. Sehingga tahanan terhadap aliran udara juga akan semakin berkurang [1].

Pengaruh $R e$ dan jarak antar titik pusat sirip dalam arah aliran udara pada $f$ sirip pin ditunjukkan pada Gambar 13 untuk susunan sirip pin segaris dan Gambar 14 untuk susunan sirip pin selang-seling. $f$ yang terjadi pada susunan segaris lebih kecil bila dibanding pada susunan selangseling. Hal ini disebabkan karena tahanan aliran udara yang terjadi pada susunan segaris lebih kecil. $S_{y} / D$ lebih berpengaruh disbanding $R e$ terhadap $f$.

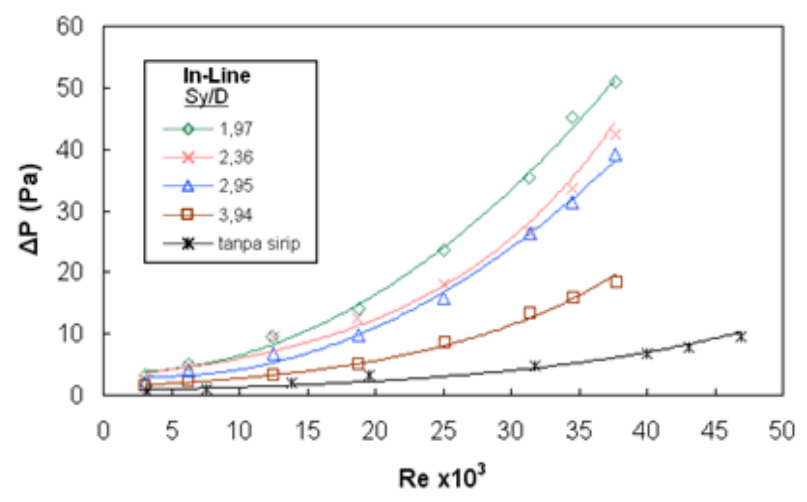

Gambar 11. Pengaruh $S y d D$ pada $\triangle \mathrm{P}$ Susunan Segaris

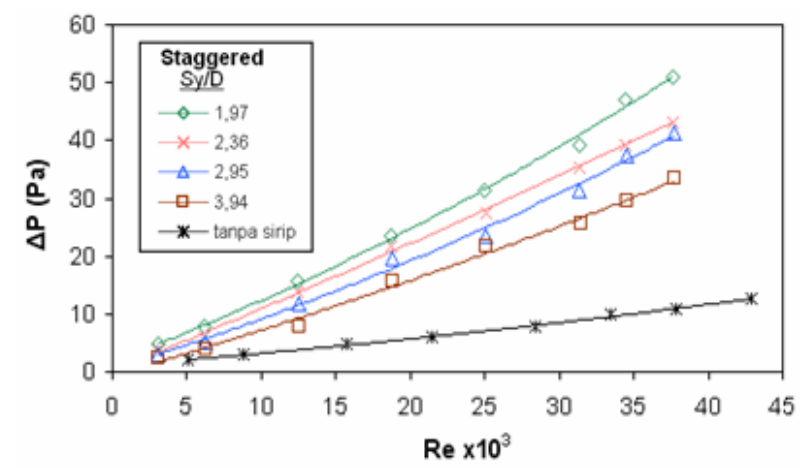

Gambar 12. Pengaruh $S y / D$ pada $\Delta \mathbf{P}$ Susunan Selang-seling

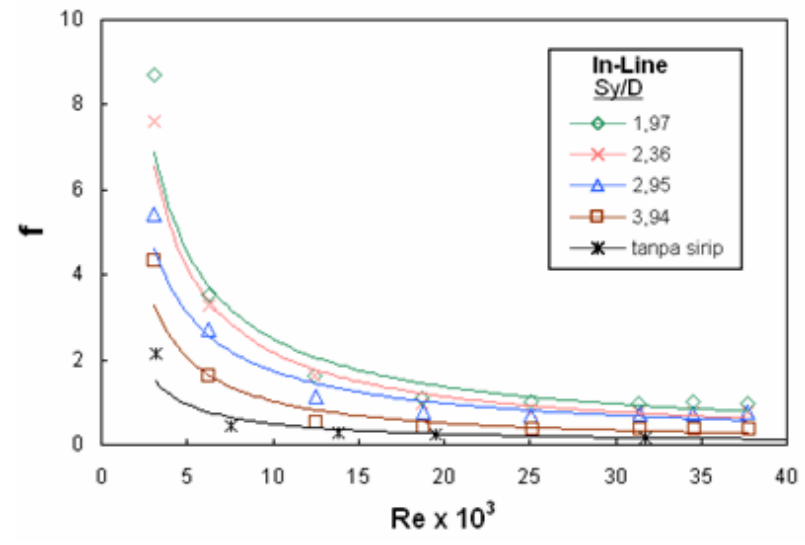

Gambar 13. Pengaruh $S y / D$ pada $f$ Susunan Segaris

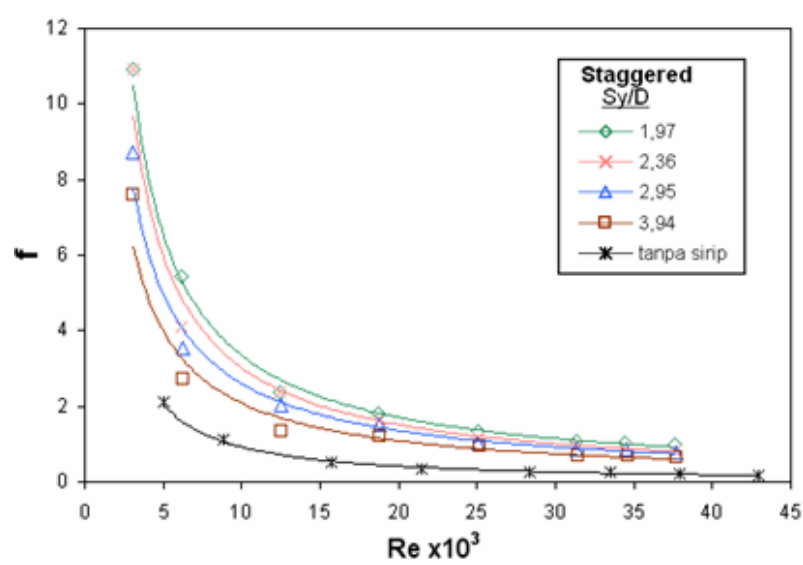

Gambar 14. Pengaruh $S y D$ pada $f$ Susunan Selangseling

Hal ini menunjukkan bahwa kenaikan $f$ seiring dengan berkurangnya nilai $S_{y} / D$ karena meningkatnya luas permukaan halangan dan efek halangan akibat kenaikan jumlah sirip pin. Pengaruh $f$ pada bilangan $R e$ serupa dengan hasil penelitian terdahulu [10].

Dari data-data penelitian dapat dibuat korelasi matematis antara $f$ yang dihasilkan oleh susunan sirip pin segaris dan selang-seling dengan $R e$, jarak antar titik pusat sirip $\left(S_{y}\right)$ dan panjang spesimen uji $(L)$ sebagai berikut [5]:

Untuk susunan segaris:

$\mathrm{f}=5696 \cdot \mathrm{Re}^{-1,091} \cdot\left(\mathrm{S}_{\mathrm{y}} / \mathrm{L}\right)^{-0,118}$

Korelasi $f$ pada Persamaan 18 berlaku valid dalam rentang bilangan Reynolds $3.100<$ Re $<$ 37.770, $\mathrm{L} / \mathrm{D}_{\mathrm{h}}=2$ dan $1,97<\mathrm{S}_{\mathrm{y}} / \mathrm{D}<3,94$.

Untuk susunan selang-seling: $\mathrm{f}=5528 \cdot \mathrm{Re}^{-1,083} \cdot\left(\mathrm{S}_{\mathrm{y}} / \mathrm{L}\right)^{-0,018}$

Korelasi $f$ pada Persamaan 19 berlaku valid dalam rentang bilangan Reynolds $3.095 \leq \mathrm{Re} \leq$ $37.741, \mathrm{~L} / \mathrm{D}_{\mathrm{h}}=2$ dan $1,97 \leq \mathrm{S}_{\mathrm{y}} / \mathrm{D} \leq 3,94$.

\section{KESIMPULAN}

Penghitungan laju perpindahan panas menunjukkan bahwa susunan segaris dan selang-seling dari 
sirip pin silinder tirus menyebabkan peningkatan perpindahan panas relatif terhadap permukaan halus (tanpa sirip). Peningkatan laju perpindahan panas ini sebagai hasil dari kenaikan luasan permukaan perpindahan panas dan turbulensi, tetapi dengan mengorbankan penurunan tekanan yang lebih besar dalam saluran segiempat. Peningkatan laju perpindahan panas dari sirip-sirip pin silinder tirus susunan selang-seling lebih baik dibandingkan susunan segaris. Pada susunan segaris dan selang seling, kenaikan bilangan Reynolds meningkatkan laju perpindahan panas, tetapi kenaikan nilai $S y / D$ meningkatkan perpindahan panas hingga $S y / D=2,36$. Pada kenaikan nilai Sy/D yang lebih besar akan menyebabkan penurunan perpindahan panas. Penurunan tekanan dan faktor gesekan meningkat seiring dengan berkurangnya nilai $S y / D$, baik untuk susunan segaris maupun selang-seling. Faktor gesekan untuk sirip pin silinder tirus susunan segaris lebih rendah dibandingkan dengan susunan selang-seling.

\section{Apendik}

$A_{s}=$ luas seluruh permukaan yang kontak dengan udara dari susunan sirip pin $\left(\mathrm{m}^{2}\right)$

$A_{t} \quad=$ luas penampang saluran segiempat $\left(\mathrm{m}^{2}\right)$

$C_{p}=$ panas jenis udara (J/kg.K)

$D=$ diameter base sirip pin silinder tirus (m)

$D_{h}=$ diameter hidrolik dari saluran udara (m)

$d=$ diameter rata-rata sirip pin silinder tirus (m)

$f \quad=$ faktor gesekan

$h=$ koefisien perpindahan panas konveksi ratarata $\left(\mathrm{W} / \mathrm{m}^{2} . \mathrm{K}\right)$

$H=$ tinggi saluran udara atau sirip pin (m)

$k=$ konduktivitas termal udara (W/m.K)

$L \quad=$ panjang plat dasar untuk susunan sirip pin (m)

$L_{t} \quad=$ panjang jarak titik pengukuran tekanan di seksi uji (m)

$\dot{m}$ = laju aliran massa udara $(\mathrm{kg} / \mathrm{s})$

$\mathrm{Nu}=$ bilangan Nuselt Saluran

$N_{f}=$ jumlah total sirip pin dalam susunan sirip pin

$\Delta P=$ perbedaan tekanan statik $\left(\mathrm{N} / \mathrm{m}^{2}\right)$

$Q$ = laju perpindahan panas (Watt)

$Q_{\text {elect }}=$ laju aliran panas dari listrik $(\mathrm{W})$

$Q_{\text {conv }}=$ laju perpindahan panas konveksi (W)

$Q_{\text {loss }}=$ laju aliran panas yang hilang dari sistem (heat loss) (W)

$Q_{\text {rad }}=$ laju perpindahan panas radiasi (W)

$Q_{\text {cond }}=$ laju perpindahan panas konduksi (W)

Re = bilangan Reynolds saluran

$S_{y}=$ jarak antar titik pusat sirip searah aliran udara (streamwise) (mm)

$S_{x} \quad=$ jarak antar titik pusat sirip melintang arah aliran udara (spanwise) ( $\mathrm{mm}$ )

$T_{\text {in }}=$ temperatur inlet dari aliran udara $(\mathrm{K})$
$T_{\text {out }}=$ temperatur outlet dari aliran udara $(\mathrm{K})$

$T_{b}=$ temperatur base plate $(\mathrm{K})$

$V=$ kecepatan rata-rata udara dalam saluran udara $(\mathrm{m} / \mathrm{s})$

$W_{b}=$ lebar plat dasar untuk susunan sirip pin (m)

$\mu \quad=$ viskositas dinamik udara $(\mathrm{kg} / \mathrm{m} . \mathrm{s})$

$v \quad=$ viskositas kinematik udara $\left(\mathrm{m}^{2} / \mathrm{s}\right)$

$\rho \quad=$ massa jenis udara $\left(\mathrm{kg} / \mathrm{m}^{3}\right)$

\section{DAFTAR PUSTAKA}

1. Naik, S., Propert, SD, Shilston, MJ, "Forced Convective Steady State Heat Transfer from Shrouded Vertically Fin Arrays, Aligned Paralel to An Undisturbed Air Stream”, Applied Energy, Vol. 26, pp. 137-158, 1987.

2. Hwang, J.J., Lui, C.C., "Detailed Heat Transfer Characteristic Comparison in Straight and 90Deg Turned Trapezoidal Ducts with Pin-Fin Arrays", Journal of Heat and Mass Transfer, Vol. 42, pp. 4005-4016, 1999.

3. Naphon, P. and Sookkasem, A., "Investigation on Heat Transfer Characteristics of Tapered Cylinder Pin Fin Heat Sinks", Energy Conversion and Management, Vol 48, pp. 2671-2679, 2007.

4. Incropera, F.P., and DeWitt, D.P., Fundamentals of Heat and Mass Transfer, 3rd. Ed., Wiley, New York, 1985.

5. Bilen Kadir, Akyol Ugur, Yapici Sinan, "Thermal Performance Analysis of A Tube Finned Surface", Energy Conversion \& Management, Vol. 26, pp. 321-333, 2002.

6. Tahat MA, Babus'Haq RF, Probert SD, "Forced Steady State Convections from Pin Fin Arrays", Applied Energy 48, pp. 335-351, 1994.

7. Jubran BA, Hamdan MA, Abdulah RM, "Enhanced Heat Transfer, Missing Pin, and Optimisation for Cylindrical Pin Fin Arrays", ASME Journal of Heat Transfer 115, pp. 576583, 1993.

8. Babus', R.F., Akintunde, K., and Probert, S.D., "Thermal Performance of A Pin Fin Assembly", Int. J. Heat and Fluid Flow, Vol. 16, , pp. 50-55, 1995.

9. Yang, K.S., Chu, W.H., Chen, I.Y., Wang, C.C., "A Comparative Study of The Airside Performance of Heat Sinks Having Pin Fin Configurations", International Journal of Heat and Mass Transfer, Vol. 50, , pp. 4661-4667, 2007.

10. Kakac, S., Shah, R.K., and Aung, W., Handbook of Single Phase Convective Heat Transfer, John Wiley and Sons, New York, 1987. 